\title{
Child Work: Attitudes and Policies of Consumption among a Group of Italian Youngsters
}

\author{
Dr. Paula Benevene \\ Libera Università Maria Ss. Assunta, (LUMSA), Rome, Italy \\ benevene@lumsa.it \\ Lisa di Lemma \\ University of Liverpool, UK

\section{Dr. Alessandro De Carlo}

Libera Università Maria Ss. Assunta, (LUMSA), Rome, Italy

Doi:10.5901/mjss.2014.v5n23p2397

\section{Abstract}

\begin{abstract}
Thesis statement Little research has been carried out on the beliefs and attitudes of young people living in the industrialised countries about child work. This research relates to attitudes, perceptions, evaluations of young Italians, in relation to child work, as well as to the consequent adoption of preventative consumption policies. Methodology The research was conducted through the use of an ad-hoc questionnaire, administrated to a group of 1,250 high school students, aged 14-18. The data were analyzed using SPSS 17. Principal Component Analyses (PCA) was performed and Cronbach's alfa were computed. Results Among key findings: participants show a limited knowledge of child work; negative attitudes towards child work are closely associated to mental representation of poverty and exploitation, but more positive attitude if work is pleasant and freely chosen by the child; the majority of the participants affirms the importance of adopting concrete preventive measures to counteract child work but, at the same time, past behaviour in consumption shows a discrepancy. Conclusions and Implications - A negative attitude towards child work does not seem to be linked to the willingness to adopt policies of consumption aimed at preventing and repressing child exploitation.
\end{abstract}

Keywords: Child Work, Consumption Behaviors, Attitudes

\section{Introduction}

According to the latest ILO (International Labour Organization) estimates, in 2008 there were about 306 million children (aged 7-17) in employment in the world (ILO, 2010). The economically developed countries are not exempted from the phenomenon of child work, where the economically active children in the age group 10-14 years are 1.7 million, while adolescents (15-17 years) are 11.5 million (Dorman, 2001). This data clearly demonstrates that the perception of child work as a phenomenon affecting only developing countries is just a widespread and incorrect prejudice.

Child work is a much debated issue, especially at international level, and the study of this phenomenon is very complex, especially because it depends on the perspective and criteria with which it is defined. The prevalent approach adopted towards child work is of the repressive type (Dawit, 2010). On the basis of this approach, child work must be progressively but also definitively abolished, because it is considered a risk factor for the moral, physical and psychicological development of the child. In the abolitionist view, work and study are considered as two opposing realities, which mutually exclude each other (Congdon Fors, 2010).

The universal validity of this approach, however, has been called into question. Opposed to the abolitionist position we find the movements of child workers in the developing countries that have re-vindicated their right to work. On this second position, the international coordination of NATs (Ninos y Adolescentes Trabajadores) is active, promoted by the Peruvian Manthoc organization. Manthoc is an organization of child and adolescent workers, ranging from 8 to 16 years of age. Analogous experiences are present in Latin America, Africa, and Asia. Thus, ENDA is present in Africa and the Caribbean, Butterflies and CWC (The Concerned for Working Children) in India, CWIN (Child Workers) in Nepal, and the MNMMR (Movimento Nacional Meninas e Meninos de Rua) in Brazil.

Those who defend child work usually affirm that this constitutes a way not only of fleeing or alleviating poverty, but also a 
form of participation in the family and social life, as well as an experience that can promote a positive representation of the self. This second approach is based on the critical valuation of the work experience of the minor, understood as a moment of socialization and of human formation even before the professional one (Admassie, 2003).

The ILO has made a distinction among child work (acceptable under certain circumstances), child labour (or exploitation) and hazardous work (extremely dangerous and detrimental forms of work, which requires immediate action from Governments in order to eradicate them, such as: slavery-like practices; direct involvement in armed conflicts; pornographic or other sexual activities) (Hagemann et al., 2006). In theory, the distinction between child work and child labour is quite clear, but the operationalization of these concepts is quite difficult, sice it offers space to discordant interpretations, so much so that this distinction has attracted criticisms for being still too vague, generic and, in the ultimate analysis, self-referring (Woodhead, 1999).

According to some scholars, the lack of a proper comprehension of the social, cultural and economic context of the child work has led to an excessively rigid attitude towards this phenomenon or to solutions driven more by emotive than weighted and conscious choices (Mehta, 2000). A relevant number of researchers have underlined the relevance of cultural or historical aspects that intervene in determining the threshold of acceptability of child work not only according to the families, the children and the social context, but also to the researchers (Cunningham, 1995; Nanjunda and Annapurna, 2006; Ungar, 2008). In fact, when approaching child work, what is conceptualized in terms of work, childhood and its care, play a determinant role (Jacquemin, 2004; Qvortrup 2003).

Some experts have stressed the need for a deeper understanding of the representations, opinions and attitudes of young people themselves on child work, in order to integrate the existing knowledge on this topic (Invernizzi, 2003 and 2005). Adolescents have proven to be competent subjects, able to autonomously express their evaluation and their point of view on their lives. In spite of this, very few researches have been carried out by interviewing youngsters (Estacio and Marks, 2005)

It is important to listen to the adolescents to find out ways of intervening and of putting together adequate theoretical instruments.

To know their point of view could contribute to the redefining of the terms of the question, allowing to develop a more effective and more realistic approach to the issue of minors' work (Myers, 1999; Boyden et al., 1998).

Above all else, it is important to know the opinions, the social representations and the attitudes towards work not only of the workers who are minors but, more in general, of all young people and adolescents. It is not opportune to limit oneself only to the gathering of data regarding child workers because, among other things, one risks researching only in areas marked by illegality or social stigmatization.

In this light it is necessary to expand our knowledge on child work also in the industrialized countries, or at least in areas not characterized by poverty or economic exploitation and social risk or poor working conditions (Benevene and Cortini, 2014).

It is certain, however, that if little is known about the opinions and attitudes of children in developing countries, much less is known about the opinions and attitudes of young people in the industrialized countries (Hobbs et al., 2007; McKechnie, and Hobbs, 1999). Nevertheless, having a deeper knowledge about their opinion is important also because this phenomenon interests the economically developed countries. In Italy the very few research studies conducted with this approach have been developed only in the sociological field, while there is an almost total absence of those carried out in the psychological field.

For this reason was considered it necessary to study the attitude of young students in an industrialized country (such as Italy) towards child work, to verify in what measure they share a social representation of child work that is marked by exploitation, poverty and the impossibility of reconciling study with work, so as to investigate the willingness and the criteria of acceptability towards carrying out of an eventual work experience (Leonard, 2004; Libòrio and Ungar, 2010).

Furthermore, the young people of the economically developed countries (including, among others, Italy) have been the target of different awareness-raising campaigns on the exploitation of children, organised by UNICEF and various non-governmental organisations, but we know little about their attitudes towards this ethical issue (Congdon Fors, 2010). In order to evaluate and assess the real impact of those campaigns, therefore, it is important to know their points of view (Doepke and Zilibotti, 2010; Manuti et al., 2012).

\section{Aim and Research Questions}

The aim of this research is to understand the attitude of young students in an industrialized country (such as Italy) towards child work, to verify in what measure they share a social representation of child work that is marked by 
exploitation, poverty and the impossibility of reconciling study with work, so as to investigate the willingness and the criteria of acceptability towards carrying out of an eventual work experience as well as the willingness to adopt preventative consumption policies

The research questions of this explorative research were as follows:

1. Which knowledge youngsters have about child labour?

2. Which mental representation do they have of the phenomenon?

3. Which are youngsters' attitudes towards preventative measures and policies of consumption?

\section{Research Method}

It was first conducted a pilot study: after having extensively examined the relevant national and international academic literature on the subject, twelve interviews were carried out with high school students, aged 15-18, in order to identify relevant themes regarding child work, to be further investigated through a questionnaire. A semi-structured interview were individually adminnistered to the students. Interviews were recorded, transcribed and encoded, in order to be submitted to content analysis. The following themes emerged: source of information and knowledge about child work; representation of child work; attitudes towards child work; causes of child work; policies of consumption preventing child work.

A questionnaire was then developed. Trained interviewers directly approached the participants at school, and distributed the questionnaires in classroom during lesson time. Participants'parents gave their informed consent and were assured of the anonymous nature of the survey. Participants were asked to take part in a university survey on young people's attitudes towards child work and were asked to fill in a paper-and-pencil questionnaire. The socio-demographic characteristics (age, educational level, type of school) were purposively balanced among the participants during the process of data collection.

\subsection{Participants}

The group interviewed consisted of 1,250 students from Italian high schools, aged 14 to 18 (mean: 16.4). Participants were $650(52.0 \%)$ students from lyceums (schools with low vocational orientation) and $600(48.0 \%)$ students from technical-professional high schools (schools with high vocational orientation). It ws thought that comparing students from different school backgrounds in terms of vocational orientation might have shown differences about representation of child work. In fact, unlike the students who attend technical-professional schools, the students attending the lyceums constitute a category of young people who do not think of inserting themselves in the short term, and in a complete way, in the world of work, because they will pursue university studies.

Males are $68.0 \%(\mathrm{~N}=850)$ of the participants. This greater presence of male subjects can be explained in the light of the fact that a higher percentage of men attend the technical-professional schools.

The socio-cultural level of the families of the students can be defined as medium-high with respect to the corresponding national average of the Italian adult population. Only $24 \%$ of the mothers and fathers have not pursued studies after completing the compulsory school. In actual fact, $48 \%$ of the parents had taken the high school diploma, and the remaining $23 \%$ are in possession of a university degree.

As regards employment, $36.3 \%$ of the fathers are public or private sector employees, while $27 \%$ are self employed professionals; as for the mothers, $37.1 \%$ declare themselves as housewives, while $32 \%$ are public or private sector employees.

\subsection{The questionnaire}

The questionnaire comprised five sections with structured and open-ended questions:

a) Information regarding the phenomenon of child work. This was measured through 8 items, asking participants to state how frequently they had heard about the presence of child work in different parts of the world. Response were coded on a 6 -step scale ranging from $1=$ never to $6=$ very often. Some examples of items are: 'How frequently did you heard about the presence of child work in Western countries?' 'How frequently did you heard about the presence of child work in Italy?'; 'How frequently did you heard about the presence of child work in developing countries?'.

This section included also questions, aimed at verifying the participants' knowledge on child work. Some examples of items are: "How many working children there are in the world today?", Do you know any international or national instrument (treaty or convention or declaration) dealing with child work? 
b) Representation of the phenomenon. Causal attributions regarding the phenomenon of child work were measured through 14 items, listing a series of potential factors determining child work. Participants had to rate their opinion through a 6 -step response scale, ranging from $1=$ a totally non-influential factor to $6=a$ maximum determining factor. Some examples of items are: In your opinion, to what extent child work is determined by "coercion from adults"; "economic poverty of the country"; "desire of learning a job"; "desire of economic independence".

c) Perceived efficacy of preventive measures meant to reduce child work. This was measured through 12 items, listing a series of potential measures aimed at preventing the exploitation of child work. Participants had to rate their opinion through a 6 -step response scale, ranging from $1=$ totally un-effective to $6=$ totally effective. Some examples of items are: 'In your opinion, to what extent the following measures may help in preventing the exploitation of child work: "prohibiting by law child and adolescent work"; "information and mobilization campaigning"; "boycotting products made via child work"; "Administer sanctions to companies employing child work".

d) Attitudes towards child work. These were measured through a semantic differential introduced by the following statement: 'How would you define child work?'. Responses were recorded on 7-steps bipolar scales featuring 20 couples of adjectives. Some examples of adjectives are: 'bad/good'; 'useless/useful'; 'dangerous/safe'.

e) Attitudes towards policies of consumption preventing child work. These were measured through 10 items. Response were coded on a 5-step Likert-type scale, ranging from $1=$ I completely agree to $5=$ I completely disagree. Some examples of items are: 'Young people should refuse to buy goods made through the exploitation of child work'; 'Young people should convince their friends not to buy goods made through the exploitation of child work'; 'Consumers have the right to know whether a good has been made through the exploitation of child work'. A final section of the questionnaire collected participants' socio-demographic data.

\section{Results}

\subsection{Information and knowledge about child work}

Participants were asked to indicate the frequency with which they had head of child work in the mass media, from friends, relatives, teachers, and organisations that deal with minors. They were asked to indicate the frequency on a scale from 1 to 6 (from 'never' to 'very often').

The first place was given to Non Governmental Organizations (NGOs) ( $N=562 ; 44.9 \%)$, followed by teachers ( $N=425$; $34.0 \%)$, then TV ( $N=367 ; 29.3 \%)$. Next came newspapers ( $N=350 ; 28.0 \%)$, relatives $(\mathrm{N}=275 ; 22.0 \%)$, while friends $(\mathrm{N}=250 ; 20.0 \%)$ came in the last place. Overall, only $33.1 \%(\mathrm{~N}=415)$ of the sample claimed to be sufficiently informed on the subject.

As for the information they had received on the subject, $72.0 \%(\mathrm{~N}=900)$ of the sample affirmed that it heard 'often or very often' about child labour in relation to developing countries, $60.0 \%(\mathrm{~N}=750)$ heard of it in relation to Asian countries, $59.1 \%(\mathrm{~N}=738)$ in relation to African countries, and $53.1 \%(\mathrm{~N}=663)$ in relation to Latin American countries.

On the contrary, $57.4 \%(\mathrm{~N}=718)$ of them asserted that they had 'never' or 'very rarely' heard of child labour in relation to economically developed countries; $33.1 \%$ ( $N=414$ ) in relation to Central or Eastern European countries; $52.0 \%$ $(\mathrm{N}=650)$ in relation to North America; and $46.0 \%(\mathrm{~N}=575)$ in relation to Italy. $47.9 \%(\mathrm{~N}=599)$ of the sample, furthermore, correctly identified Asia as the continent where the greatest number of child workers is present. Only $14.9 \%(\mathrm{~N}=187)$ were able to remember any international instruments (such as the ILO Conventions and the International Convention on Child Rights) that deal with the child work question and only 18.0\% ( $N=225)$ knew there are about 306 million minors aged 5-17 involved in economic activities in the world. This corresponds to the data made known by the ILO (2010).

\subsection{Representation of the phenomenon}

A scale from 1 to 6 (from "a totally non-influential factor" to a "maximum determining factor") was used to research the mental representation of child labour. Principal Component Analyses (PCA) was performed to analyze the data and Cronbach's alfa were computed.

The first factor (explaining $26 \%$ of the variance and which was called 'Child work as consequence of the political and economic context'), brings out how certain aspects are considered important, such as the lack of inspections on the places of work, the disinterest or connivance of governments, the economic dependence of poor countries, and the lack of adequate laws and their enforcement, the presence of multinational corporations, the constriction on the part of the 
adults, and the maximisation of profit for the employers. A highly critical representation of the phenomenon was evident. The second factor extracted (explaining 17.5\% of the variance, and which was called 'Child work as consequence of personal and family conditions') emphasises the socio-environmental aspects of the representation of the phenomenon, in so far as child labour would depend in a significant measure on failure in school, the haste to learn a trade, the desire for economic independence, the youngster's desire to help the family, the demands posed by the poverty of the families. The third factor extracted (explaining $11.5 \%$ of the variance, and which was called 'Child work as consequence of lack of protection for the minor') shows that child work depends also on economic poverty, on abandonment or disinterest by the family.

Table 1: Causal Attribution of Child Work

\begin{tabular}{|c|c|c|}
\hline Factors & Actual variance & Cronbach's Alpha \\
\hline F1 'Child work as consequence of the political and economic context' & $26 \%$ & .8402 \\
\hline F2 'Child work as consequence of personal and family conditions' & $17.5 \%$ & .7628 \\
\hline F3 'Child work as consequence of lack of protection for the minor' & $11.5 \%$ & .6042 \\
\hline
\end{tabular}

The comparison between the mean of the responses of the students of the technical-professional schools and those of the lyceum students, conducted with one-way anova analysis, brought out results significantly $($ sig. $=.000)$ different relating to the will to learn a trade, scholastic failure, the desire for economic independence, and the desire to help the family. Different from the lyceum students, the above-indicated variables were valued as extremely determining causes of the phenomenon of child labour by the group of students from the technical-professional institutes, and can be traced to a dimension of the capacity of autonomous and responsible choice of the child towards insertion in the world of work.

The representation of $68.0 \%(\mathrm{~N}=850)$ of the participants, hold that work prevents the minor from developing friendships with his/her peers, while $58.0 \%(\mathrm{~N}=750)$ hold that the exercise of a work activity might compromises the youngster's self-esteem.

\subsection{Acceptability of Child Work}

Asked to express an opinion as to who should take the decision that a child should begin to work, $31.4 \%(\mathrm{~N}=392)$ of the participants held that the criteria should be determined by law and a small percentage ( $N=111 ; 8.8 \% \%$ ) held that it was more adequate to entrust the matter to a tribunal or a judge for minors. However one third of participants $(\mathrm{N}=450 ; 36.0 \%)$ held that it should be the minor him/herself who should decide or possibly with his family ( $N=297 ; 23.8 \%)$.

Besides, $74.3 \%(\mathrm{~N}=929)$ of the participants indicates that the minors who work in show business are to be considered very fortunate, and $64.1 \%(\mathrm{~N}=802)$ hold that work which brings popularity and fame to the minor cannot be considered a true and proper work.

\subsection{Attitudes towards child work}

To measure the attitude to child work, a seven-point semantic differential, constituted by 20 couples of bi-polar adjectives, was used. The analysis factorial and the inter-item correlation scale highlighted a negative attitude in almost all the couples of adjectives, with the exception of the couple 'de-responsibilising-responsibilising' in which the sample was oriented to the polarity 'responsibilising'. As for possible intervention on child labour, 59.2\% ( $N=741$ ) of those interviewed considered it opportune to adopt different criteria, according to the cultural, economic and social situation of the country, while $34.5 \%(\mathrm{~N}=432)$ expressed a different opinion, holding that the criteria adopted should be the same all over the world.

Asked to express an opinion as to who should take the decision that a child should begin to work, $30.8 \%(\mathrm{~N}=385)$ of those interviewed held that the criteria should be determined by law; $31.1 \%(\mathrm{~N}=389)$ held that it should be the minor him/herself who should decide together with the family, while $20.4 \%(\mathrm{~N}=256)$ believed that the responsibility should fall only on the child. A small percentage of the sample ( $\mathrm{N}=129 ; 10.3 \%)$ held that it was more adequate to entrust the matter to a tribunal or a judge for minors.

\subsection{Perceived efficacy of measures meant to reduce child work.}

A group of affirmations were given to the group of studies interviewed in which were described the measures used to 
prevent and combat the exploitation of child work, and they were asked to value them on a scale from 1 to 6 . Principal Component Analyses (PCA) was performed to analyze the data and Cronbach's alfa were computed; the two factors extracted were rotated with the varimax method and explain $49 \%$ of the total variance (see table 2 for more details).

From the first factor (explaining $29.7 \%$ of the variance and which was called 'Effectiveness of intervention against child work at macro level') there emerges the necessity to prohibit by law child work, to carry out inspections on places of work, to enforce norms that punish exploitation and consent the adolescent to work, to improve the scholastic system, to put pressure on governments, to apply sanctions to companies that use child workers, to carry out information campaigns, to offer economic support o families and to hear the opinion of children that work.

The second factor (explaining 19.0\% of the variance and which was called 'Effectiveness of intervention against child work at meso and micro level'), highlights a favourable attitude to boycotts of products made by child work, to take away from families the children that work, and to oblige the children that work to go to school.

Table 2: Perceived Effectiveness of Interventions Against Child Work

\begin{tabular}{|l|c|c|}
\hline Factors & Actual variance & Cronbach's Alpha \\
\hline F1 'Effectiveness of interventions against child work at macro level' & $29.7 \%$ & .8319 \\
F2 'Effectiveness of interventions against child work at meso and micro level' & $19.0 \%$ & .6599 \\
\hline
\end{tabular}

A comparison between the mean of the responses for the technical-professional institutes and those of the lyceum students, conducted on the one-way anova analysis, has given significantly (sig. $=.000$ ) different results in relation to the four interventions: to carry out inspections on the places of work, to put pressure on governments, to remove child workers from families, to oblige children who work to go to school. While the lyceum school students hold that the normative-enforceable measures are the more effective, the students of the technical-professional institutes hold that direct intervention on the families and children are effective measures.

\subsection{Policies of consumption}

A further scope of the research was the gathering of attitudes of participants with respect to the adoption of policies of consumption of goods produced by the exploitation of child work.10 items were proposed, to which the participants were asked to respond using a scale (from 1 to 6) of agreement or disagreement. Principal Component Analyses (PCA) was performed to analyze the data and Cronbach's alfa were computed; the two factors extracted were rotated with the varimax method and explain $66.7 \%$ of the total variance (see table 3 for more details).

The first factor (explaining about $41 \%$ of the variance, and which was called 'effectiveness of the adoption of economic behaviour at the micro level') brings out how participants consider effective the interventions against child work, such as the application of economic sanctions, the application of codes of conduct on the part of producing companies that exploit child labour, making families and friends aware of the right of information for consumers.

The second factor (explaining $25.8 \%$ of the variance, and which was called 'the effectiveness of the adoption of economic behaviour at the meso level'), highlights the effective potential and the opportunity for intervention by the consumers on producers who sell goods produced with the exploitation of child work, and the consequent boycott of merchandise.

Table 3: Attitudes Towards Adoption of Policies of Consumption

\begin{tabular}{|l|c|c|}
\hline Factors & Actual variance & Cronbach's Alpha \\
\hline F1 'Effectiveness of the adoption of economic behavior at micro level' & $40.9 \%$ & .9087 \\
\hline F2 'Effectiveness of the adoption of economic behavior at meso level' & $25.79 \%$ & .7821 \\
\hline
\end{tabular}

As regards the choice of past consumption, only $21.1 \%(\mathrm{~N}=263)$ of the participants said they had refused to a product made through the exploitation of child work, the remaining part of participants affirmed that either they never posed themselves the problem.

\section{Conclusions}

The majority of the participants affirmed they hold a limited knowledge of child work, even if it was not completely inaccurate. This data finds confirmation in the fact that less than $50 \%$ of the participants correctly identified Asia as the continent in which the greatest number of child workers is present. 
It is important to note that the sources of information on child work, according to what those interviewed stated, come in the most part from the NGOs, teachers and the media. In particular, the NGOs in Italy were, and still are very active in involving schools in campaigns of information and awareness raising about child work, as well as in the promotion of policies of consumption, aimed at counteracting the exploitation of child work in developing countries. This may explain why, according to the participants, the information they received on child work is concentrated almost exclusively on developing countries, and first among these are the African countries.

It has to be remarked that most participants considered uncorrectly child work as a phenomenon linked almost exclusively to the developing countries. This belief is uncorrect, not only in consideration of the ILO estimates (Dorman, 2001) but also because in Italy a research study by the CGIL according to which at least 350,000 minors are working illegally in Italy (Paone \& Teselli, 2000) is still receiving a considerable attention by the media, the trade unions, third sector's organizations, the political world and, more in general the public opinion.

Even if it is not possible to deduce this from an analysis of the data, it would be interesting, as a further development of this research, to verify if the information received through these interventions - predominantly aimed at presenting the reality of the developing countries - are somehow linked to the representation of child work as a phenomenon of little significance in Italy and in the industrialized countries.

In fact that from the data collected emerges a perception on child work linked to economic distress and poverty, while, on the contrary, according to the participants, the data and information received on the phenomenon do not relate to the western, industrialized countries.

The representation of child work as a phenomenon linked to the situation of developing countries emerges also from the analyses of the causal attribution of child work, in particular from the weight of the items that attribute child work to external factors that are beyond the youngster's control, such as: the lack of inspections on the places of work, the disinterest or connivance of governments, the economic dependence of poor countries, and the lack of adequate laws and their enforcement, the presence of multinational corporations, the constriction on the part of the adults, and the maximisation of profit for the employers.

This causes would seem to present the figure of the child worker as a passive victim, pushed to work by distressing situations arising from his family as well as the social and economic and environment. In other words, the child worker would seem to be someone who is unwillingly submitted to be a worker.

The personal motivations (such a the desire to learn a job, the desire for economic independence, failure at school), linked to the individual choice of the child worker, are in fact represented as weaker and, in any case, include a negative element, such as failure at school. In this respect, it has to be noted that very often, in the debate on child work, both the academic literaure and the media, mention the difficulty/impossibility of reconciling study with work.

It emerges clearly that the participants expressed a generally negative attitude towards child work. At the same time, this representation of child work seems to proposes a double perception of the phenomenon, since according most participants, teen agers who work in show business are considered very fortunate (Cortini et al., 2010). In addition, according the majority of participants, the employment in the show business world is not to be considered a proper work, despite the fact that the National Centre for the Documentation and Information on Childhood and Adolescence, linked to the Ministry of Welfare, considers it as such, and furthermore a quite demanding and potentially dangerous one for the wellbeing of the youngsters (Centro Nazionale di Documentazione Analisi per l'Infanzia e l'Adolescenza, 1999).

These data would seem to suggest therefore that the negative attitude towards child work is not rigid, and may change on condition that some criteria are respected, such as the free choice of the child, or the doing of gratifying work such as that offered by the show business world.

This hypothesis seems to be suggested also by the response of the majority (59.4\%) of participants, who, as regards possible intervention on child work, have found it opportune to adopt different criteria, according to the cultural, economic and social situation of the country. As regards this second (positive) attitude, however, it would be necessary, later on, to deepen the research, especially in regard to establish the criteria of acceptability of work done by children. In fact, it can be hypothesized that adolescents can express a more positive attitude towards types and forms of work compatible with his age and his general wellbeing.

It is necessary, therefore, to investigate those aspects - both positive and negative - of work done by minors in such conditions that do not put at risk the moral, physic and physical development of the youngsters (Falco et al., 2008). For this reason it would be important to know the opinions, valuations, attitudes of children that work or have worked combining work with study, because the presumed incompatibility of these two experiences in the academic literature is maybe the strongest motivations for the unacceptability of any kind of work experience performed by a child.

As far as policies of consumption are concerned, a substantial disagreement emerged between attitude and belief and the consequent behaviour: the majority of participants in fact affirms the importance of adopting concrete preventive 
measures to counteract child work but, at the same time, past behaviour in consumption shows a discrepancy, since only one fifth ( $\mathrm{N}=263 ; 21.1 \%)$ of them said they had ever refused to buy a product made through the exploitation of child work. A negative attitude towards child work does not seem to be linked to the willingness to adopt policies of consumption aimed at preventing and repressing child exploitation. In fact only 39\% of participants hold that boycotts could help resolve the problem of child work. In other words, the willingness to adopt policies of consumption might be correlated to a positive evaluation of their effectiveness and to the attribution of the causes of child work to external factors linked to the economic, social and cultural context. This aspect, however, deserves a deeper inisight in future research.A strong limit to this research and, more in general, to the study of attitudes towards child work is, in fact, the lack of a clear, univocal and universally accepted definition of 'child work' as well as the 'child worker'. The term 'child work', even when it is explicitly distinct from exploitation, is sometimes superimposed on this, making conceptually weak both the terms and the threshold between these two phenomena. As a result of this confusion, we did not considered opportune to add questions on the eventual past or present work experiences of participants. A further consequence of this confusion is the lack of a study of the perspectives of minors who work, except in contexts of exploitation, marginalization and social risk.A qualitative research, probably, carried out through free or semi-structured interviews could constitute a second phase of this first exploratory investigation, of which the present research study is a part.

\section{References}

Admassie, A. 2003. "Child Labour and Schooling in the context of a Subsistence Rural Economy: Can They Be Compatible?. International Journal Of Educational Development 23: 167-185.

Benevene, P., Cortini M (2014). "Child Labor and Adolescent Labor: May They Become a Learning Opportunity?" The International Journal of Pedagogy and Curriculum, in press.

"Understanding the meanings of work. A qualitative research with a group of Mexican teen-agers. European Journal of Social Sciences 34: 162-176.

Boyden, J., Ling, B., \& Myers, W. 1998. What Works for Working Children. Stockholm: Radda Barnen and UNICEF.

Centro Nazionale di Documentazione Analisi per l'Infanzia e l'Adolescenza. 1999. Minori e lavoro minorile in Italia: questioni aperte. Firenze: Istituto degli Innocenti.

Congdon Fors, H. 2010. "Child labour: A review of recent theory and evidence with policy implications". Journal of Economic Surveys 26: 738-752.

Cortini, M., Vicenti, A., \& Zuffo, R. G. 2010. Celebrity endorsement and congruence: An experimental study. International Journal of Interdisciplinary Social Sciences 5: 325-336.

Cunningham, H. 1995. Children and childhood in Western society since 1500. London and New York: Longman.

Dawit, S. 2010. "Determinants of Child Labor versus Schooling in Rural Ethiopia". European Journal of Social Sciences 17: 414-425.

Doepke, M., \& Zilibotti, F., 2010. "Do International Labor Standards Contribute to the Persistence of the Child-Labor Problem?". Journal $f$ Economic Growth 15: 1-31.

Dorman, P., 2001. Child Labour in the Developed Economy. ILO/IPEC Working Paper. Geneva: ILO.

Estacio, E.V., \& Marks, D.F., 2005. "Child Labour and the International Labour Organizations Convention 182: A Critical Perspective". Journal of Health Psychology 3: 475-484.

Falco, A., Dal Corso, L., De Carlo, A., \& Di Sipio, A., 2008. "Effects of Temporary Job Contracts on the Well-Being of Individuals and Organizations". TPM - Testing, Psychometrics, Methodology in Applied Psychology 15: 193-209.

Hagemann, F., Diallo, Y., Etienne, A., \& Mehran, F. 2006. Global Child Labour Trends 2000-2004. Geneva: ILO.

Hobbs, S., Stack., N., McKechnie, J, \& Smillie, L. 2007. "Talking About work: School Students' Views on Their Paid Employment". Children \& Society 21: 123-135.

Invernizzi, A., 2005. "Perspective on Children's Work in the Algarve (Portugal) and their Implications for Social Policy". Critical Social Policy 25: 198-222.

Invernizzi, A. 2003. "Street-Working Children and Adolescents in Lima: Work as an Agent of Socialization". Childhood 10: 319 - 341.

International Labour Organization (ILO), 2010. Accelerating Action Against Child Labour - ILO Global Report on Child Labour 2010. Geneva: ILO.

Jacquemin, M.Y. 2004. “Children's Domestic Work in Abidjan, Côte D'ivoire. The Petites Bonnes Have the Floor”. Childhood 11: 383-397.

Leonard, M. 2004. "Children's Views on Children's Right to Work: Reflections from Belfast". Childhood 11: 45 - 61.

Liebel, M., 2007. "Paternalism, Participation and Children's Protagonism". Children, Youth and Envirornments 17: 56-73.

Libòrio, R.M.C., \& Ungar, M., 2010. "Children's Perspectives on Their Economic Activity as a Pathway to Resilience. Children \& Society 24: $326-338$.

Manuti, A., Traversa, R., \& Mininni, G., 2012. "The dynamics of sense making: A diatextual approach to the intersubjectivity of discourse". Text and Talk 32: 39-61.

McKechnie, J., \& Hobbs, S., 1999. "Child labour: the view from the North". Childhood 6: 89 - 100.

Mehta, P., 2000. "Child Labour: a Different Perspective". Development 2: 40-42.

Myers, W.E. 1999. "Considering Child Labour: Changing Terms, Issues and Actors at the International Level". Childhood 6: 13 - 26.

Nanjunda, D.C., \& Annapurna, M., 2006. "Small Hands in Silicon City-Bangalore: Some Facts and Experiences at Grass Root Level", Journal of Social Sciences 13, pp. 151-156.

Paone, G., \& Teselli, A. 2000. Lavoro e lavori minorili. Roma: Ediesse.

Qvortrup J. 2003. The Colonization of Children's Work. Dansk Sociologi 2: 25-38.

Ungar, M. 2008. "Resilience Across Cultures". British Journal of Social Work 38: 218-235.

Woodhead, M. 1999. "Combatting Child Labour. Listen to What the Children Say". Childhood 6: 27-49. 